\title{
PEMANFAATAN CAMPURAN KARBON AKTIF DARI ARANG BAMBU DAN SERBUK HABBATUSSAUDA SEBAGAI ADSORBEN DALAM PENYARINGAN AIR BAKU UNTUK AIR MINUM
}

\author{
Hasmalina, Musyirna Rahmah Nasution
}

Universitas Muhammadiyah Riau,

Sekolah Tinggi Ilmu Farmasi Riau

\begin{abstract}
ABSTRAK
Daerah Riau merupakan dataran rendah umumnya dengan tipe tanah gambut sehingga air yang didapatkan masih kurang layak untuk dikonsumsi, karena berwarna kuning kecoklatan dan memiliki kandungan ion logam-logam, anion serta mikroba. Cakupan pelayan air bersih sebagai air baku air minum juga masih sangat rendah. Perusahaan penyedia air bersih (Perusahaan Air Minum/PAM) hanya mampu memasok kebutuhan di kota-kota saja dengan kuantitas yang juga masih kecil. Akibatnya sebahagian besar masyarakat tidak terjangkau oleh pelayanan air bersih umumnya menggunakan air tanah atau air permukaan untuk keperluan hidupnya sehari-hari. Pada penelitian ini telah dihasilkan alat saringan air dengan memanfaatkan campuran karbon aktif dari arang bambu dan habatussauda yang memiliki kemampuan sebagai adsorben. Nilai parameter fisika, kimia dan mikrobiologi air baku yang dihasilkan dari alat saringan ini masih dibawah ambang batas baku mutu air baku air minum yang ditetapkan pada Peraturan Pemerintah No 82 Tahun 2001 tentang pengelolaan kualitas air dan pengendalian pencemaran air, Peraturan Menteri Kesehatan RI tentang Persyaratan Kualitas Air Minum (Permenkes RI Nomor 492/MENKES/PER/IV/2010 dan Kepmenkes No. 907/2002).
\end{abstract}

Kata Kunci: Karbon Aktif, bambu, habatussauda, adsorben

\section{PENDAHULUAN}

Di daerah Riau air baku untuk air minum sulit didapatkan, walaupun dengan membuat sumur gali atau sumur bor yang cukup dalam, disebabkan Riau merupakan dataran rendah umumnya dengan tipe tanah gambut sehingga air yang didapatkan masih kurang layak untuk dikonsumsi, karena berwarna kuning kecoklatan dan memiliki kandungan ion logam-logam, anion serta mikroba. Cakupan pelayan air bersih sebagai air baku air minum juga masih sangat rendah. Perusahaan penyedia air bersih (Perusahaan Air Minum/PAM) hanya mampu memasok kebutuhan di kota-kota saja dengan kuantitas yang juga masih kecil. Akibatnya sebahagian besar masyarakat tidak terjangkau oleh pelayanan air bersih umumnya menggunakan air tanah atau air permukaan untuk keperluan hidupnya sehari-hari.

Pengembangan materi penyerap (adsorben) yang berasal dari material murah untuk pengolahan air bersih dan limbah cair pada dasarnya sangat dibutuhkan, karena mahalnya karbon aktif komersil dan sulitnya pengadaan di negara berkembang seperti Indonesia. Bahan dasar utama yang dipergunakan sebagai karbon aktif adalah material organik dengan kandungan karbon yang tinggi, antaralain bambu, kayu, batu bara, tempurung kelapa, atau serbuk gergaji. Riau memiliki sumberdaya hutan dengan potensi tanaman bambu yang cukup besar. Pemanfaatan bambu masih terbatas pada bahan bangunan dan pembuatan prabot rumah tangga. Arang aktif bambu menghasilkan adsorpsi tinggi Jika dibandingkan dengan arang aktif yang dibuat dari arang bakau dan arang tempurung kelapa dengan angka adsorbsi melebihi standar AWWS dan SII, serta masuk dalam kisaran kelompok arang aktif komersial. Arang bambu memiliki gugus fungsi seperti $-\mathrm{OH}$ dan $\mathrm{C}=\mathrm{O}$. Gugus fungsi ini dapat membentuk kompleks dengan ion logam melalui interaksi gugus fungsi sebagai ligan dengan kation logam (Kannan, N., And Veemaraj, 2009).

Biji habatussauda/jintan hitam (Nigella Sativa) tanaman yang telah dikenal memiliki potensi antimikroba dan secara luas telah 
digunakan sebagai obat herbal berbagai macam penyakit dan dilaporkan telah menunjukkan efek farmakologis yang meliputi antihelmintik, anticestoda, antischistosoma, antibacterial, anti fungi, anti viral, antioksidan dan aktivitas antiinflamasi serta dapat meningkatkan respon imun yang dimediasi sel $\mathrm{T}$ (Abdulelah dan Abidin, 2007).

Teknologi pengolahan air bersih dengan menggunakan alat saringan yang terdiri dari batu kerikil, pasir, ijuk telah dikenal oleh sebahagian masyarakat tetapi alat saringan yang menggunakan batu kerikil, pasir, ijuk dan campuran karbon aktif arang bambu dan habatussauda sebagai adsorben untuk mendapatkan air bersih sebagai air baku air minum sesuai parameter yang ditetapkan oleh Peraturan Pemerintah No 82 Tahun 2001 tentang pengelolaan kualitas air dan pengendalian pencemaran air, Peraturan Menteri Kesehatan RI tentang Persyaratan Kualitas Air Minum (Permenkes RI Nomor 492/MENKES/PER/IV/2010 dan Kepmenkes No. 907/2002). belum pernah dilakukan. Analisis kualitas air baku air minum meliputi analisa parameter fisika, kimia dan mikrobiologi.

Melalui penelitian ini diharapkan ditemukan solusi alternatif guna mendapatkan teknologi pengolahan dan alat/sistem saringan yang mudah, murah dan efektif untuk mengolah air tanah dan air permukaan menjadi air bersih yang layak sebagai air baku air minum dengan memanfaatkan daya serap (adsorpsi) karbon aktif arang bambu dan anti mikroba yang terdapat pada habatusauda.

\section{METODOLOGI PENELITIAN}

\section{Alat dan Bahan}

Alat-alat yang digunakan pada penelitian ini diantaranya adalah botol / wadah saringan, keran, lem PVC, furnace (merk Nabertherm), Oven, alat penyerbuk, ayakan diameter $1 \mathrm{~mm}$, cawan goach, spektrofotomeri UV-Vis, Atomis Absorption Spektroskopi (AAS), Oven, Inkubator, peralatan gelas, autoklaf $\left(\mathrm{Gea}^{\circledR}\right)$, bunsen, cawan Petri, gunting, hot plate, inkubator $\left(\right.$ Memmert $\left.^{\circledR}\right)$, kain kasa, kapas, kertas koran, kertas saring, Laminar Air Flow (LAF), lampu spiritus, pipet mikro
$\left(\mathrm{Nesco}^{\circledR}\right)$, rak tabung reaksi, spatel, timbangan analitik $\left(\mathrm{Kern}^{\circledR}\right)$, dan vorteks $\left(\mathrm{AsOne}^{\circledR}\right)$.

Bahan-bahan yang digunakan adalah: batang bambu untuk karbon aktif, biji Habatussauda, pasir halus, batu kerikil, ijuk, aguades, larutan standar logam $\mathrm{Fe}, \mathrm{Mn}, \mathrm{Pb}, \mathrm{Cu}, \mathrm{Zn}, \mathrm{Ni}, \mathrm{Cd}$ dan $\mathrm{Cr}$, $\mathrm{H}_{2} \mathrm{SO}_{4}$ pekat, larutan standar anion sulfat, nitrat, nitrit, fluoride, EDTA, EBT, Buffer Asetat, alkohol 70\%, aquadest, potato dextrosa agar (PDA) $\left(\right.$ Merk $^{\circledR}$ ) dan Nutrien agar (NA), media lactose Broth, dan brilliant green lactose $2 \%$ (BGLB).

\section{Prosedur Kerja}

Persiapan bahan dasar arang bambu dan serbuk habbatussauda

Batang bambu dipotong-potong kecil, setelah dibersihkan. Dijemur di bawah sinar matahari hingga menjadi kering, setelah kering, dibakar sampai menjadi arang bambu. Arang Bambu (Karbon) yang diperoleh, digerus, dibasahi dengan sedikit air. Kemudian diaktivasi secara fisika dengan pemanasan dengan metode tungku sederhana dan lubang tanah. Karbon aktif siap untuk untuk diaplikasikan

Serbuk biji jintan hitam merupakan serbuk yang berasal dari biji jintan hitam yang telah dikeringkan dalam oven dengan suhu $105^{\circ} \mathrm{C}$ sampai kering atau lebih kurang selama tiga jam, diserbuk dengan mesin penyerbuk dan disaring dengan ayakan diameter lubang $1 \mathrm{~mm}$. Serbuk habatussauda siap diaplikasikan.

\section{Proses Pembuatan Saringan}

Siapkan wadah dan bahan-bahan yang diperlukan. Disusun bahan-bahan dalam wadah dimulai dari kerikil besar + kerikil halus (D) kemudian ijuk dan pasir halus (C) kemudian karbon aktif bambu + habbatussauda (B) bagian atas di tambahkan lagi pasir halus + ijuk (A)

Penentuan Parameter Fisika, Kimia dan Mikrobiologi Air Hasil Saringan

\section{Parameter Fisika}

Beberapa parameter fisika yang ditentukan diantaranya: Bau, Rasa, Suhu, Warna dan Jumlah Zat Padat terlarut (TDS)

\section{Parameter Kimia}

Beberapa parameter kimia yang ditentukan diantaranya: logam besi, mangan, timbal, seng, kadmium, nikel dan kromium valensi 6 dengan 
metode spektorfotometri serapan atom, kesadahan dengan metode titrasi kompleksometri, anion sulfat, florida, nitrate, nitrit, dan klorida dengan metode spektrofotometri UV-Vis

\section{Parameter Mikrobiologi}

Penentuan Daya Serap Arang Aktif dengan Pengujian Angka lempeng total bakteri dan angka kapang dengan Metoda Tuang

Sebanyak $5 \mathrm{~g}$ arang aktif dimasukkan ke dalam alat pecobaan, lalu dialirkan $100 \mathrm{ml}$ air. Kemudian kran tabung dibuka dan ditampung hasil saringan. Hasil tampungan dipipet sebanyak $1 \mathrm{ml}$ dan dibuat larutan dengan konsentrasi10 $0^{-1}$. Larutan tersebut dibuat serial konsentrasi $10^{-2}, 10^{-}$

${ }^{3}$, dan $10^{-4}$ Sebanyak $1 \mathrm{ml}$ larutan pada konsentrasi $10^{-2}$ dan $10^{-4}$ dituangkan ke dalam cawan petri. Kemudian ditambahkan media NA dan atau PDA sebanyak 10-15 ml. Cawan diputar diatas meja datar hingga bercampur merata, lalu media dibiarkan memadat. Cawan petri yang berisi media NA diinkubasi selama 24 jam pada suhu $37^{\circ} \mathrm{C}$ dalam keadaan terbalik. Sedangkan cawan petri yang berisi media PDA diinkubasi pada temperatur ruang selama $72 \mathrm{jam}$. Kemudian diamati mikroba yang tumbuh dengan menghitung jumlah koloni yang tumbuh dengan alat colony counter pada tiap cawan. Kemudian dihitung angka lempeng total bakteri (ALT) dan angka kapang dengan mengalikannya dengan faktor pengenceran.

\section{Pemeriksaan Most Probable Number (MPN) Coliform dan Escherichia coli}

Tes Perkiraan (persumtive test)

Disiapkan 7 tabung reaksi yang berisi $10 \mathrm{ml}$ media lactose Broth pada tabung pertama dimasukkan $10 \mathrm{ml}$ sampel. Pada tabung 6 dimasukan $1 \mathrm{ml}$ dan tabung ke 7 dimasukan 0,1 $\mathrm{ml}$ sampel. Kemudian dikocok perlahan agar sampel menyebar homogen, inkubasi pada suhu $37^{\circ} \mathrm{C}$ selama 48 jam. Bila terdapat gas atau gelembung halus hasil positif dan dilanjutkan dengan uji penegasan.

\section{Tes penegasan (confirmed test)}

Merupakan lanjutan dari tes perkiraan dengan memindahkan 1-2 ose tabung media LB (lactose broth) yang positif ke dalam dua seri tabung reaksi yang berisi $10 \mathrm{ml}$ brilliant green lactose $2 \%$ (BGLB), 1 seri tabung diinkubasi pada suhu $35-37^{\circ} \mathrm{C}$ selama 48 jam untuk memastikan adanya coliform dan 1 seri tabung reaksi yang lain diinkubasi pada suhu $44^{\circ} \mathrm{C}$ selama 48 jam untuk memastikan adanya escherica coli. Dengan melihat tabel MPN.

\section{HASIL DAN PEMBAHASAN \\ Pembuatan Arang Aktif Bambu}

Proses pembuatan arang bambu diawali dengan mencari metode yang tepat untuk menghasilkan rendemen arang bambu yang tinggi dan dapat diterapkan secara mudah oleh masyarakat. Metode awal yang dilakukan adalah Metode Lubang Tanah, yang merupakan tungku dari tanah yang digali dan diberi lubang sebagai jalan masuk bahan bakar dan bambu yang akan dijadikan arang. Metode ini hanya mendapatkan arang bambu dengan rendemen kecil dari $10 \%$.

Proses pembuatan arang bambu yang akan diaktifkan sebagai adsorben selanjutnya dilakukan dengan Metode Tungku Sederhana. Metode ini memanfaatkan tabung berupa kaleng bekas ukuran 30 x $50 \mathrm{~cm}$. Bambu disusun di dalam tabung, kemudian tabung ditutup dengan rapat (posisi vertikal) dengan posisi $5 \mathrm{~cm}$ lebih tinggi dari permukaan tanah. Setelah bambu terbakar lebih kurang 1 jam , tungku pembakaran ditutup dengan pasir dengan diberi celah lebih kurang $10 \mathrm{~cm}$ untuk tempat memasukkan bahan bakar/kayu pada 3 sisinya dan dibiarkan proses pembakaran berlanjut selama 4 jam, kemudian tabung didinginkan dan ditutup cerobong tabung. Dengan metode ini diperoleh rendemen arang bambu 50\% dari berat awal bambu yang di bakar (1/2 tabung pembakaran).

Arang bambu yang telah dihasilkan dari proses pembakaran bambu diaktifkan secara fisika dalam furnace pada suhu $900{ }^{\circ} \mathrm{C}$ selama 150 menit, kemudian didinginkan sampai suhu furnace turun menjadi $200{ }^{\circ} \mathrm{C}$ dan dipanaskan lebih lanjut dalam oven pada suhu $105{ }^{\circ} \mathrm{C}$ selama 15 menit. Arang bambu yang telah aktif didinginkan dalam desikator dan disimpan dalam wadah tertutup. 
Analisa Parameter Fisika, Kimia Dan Mikrobiologi Air Baku

Air menjadi masalah yang harus mendapat perhatian yang seksama dan cermat karena untuk mendapatkan air yang bersih sesuai dengan standar tertentu saat ini menjadi barang yang mahal karena air sudah banyak tercemar oleh bermacam-macam limbah dari hasil kegiatan manusian baik dari limbah kegiatan rumah tanga, limbah dari kegiatan industri dan kegiatankegiatan lainnya. Ketergantungan manusia terhadap air pun semakin besar sejalan dengan perkembangan penduduk yang semakin meningkat.

Dalam penelitian ini sampel yang diambil adalah salah satu air sumur galian rumah penduduk di Kelurahan Sukamaju Kecamatan Sail Kota Pekanbaru. Hal ini dikarenakan salah satu tujuan penelitian adalah untuk membuat alat saringan yang berfungsi untuk mendapatkan air baku air minum, sehingga metode sampling air yang representatif tidak diperlukan. Dalam penelitian ini lebih difokuskan untuk mengukur kekuatan atau kemampuan alat saringan air bukan tingkat pencemaran air di kelurahan tersebut, sehingga tidak lagi memperhatikan faktor yang mempengaruhi dalam analisa parameter pencemaran kualitas air seperti musim, kedalaman sumur, jumlah titik sampling yang dikaitkan dengan jenis dan jumlah aktivitas penduduk yang menghasilkan pencemaran air.

Rancangan percobaan yang dilakukan disesuaikan dengan tujuan penelitian yaitu membuat alat saringan yang memanfaatkan campuran arang aktif bambu dan serbuk habbatussauda untuk menghasilkan air baku untuk air minum. Rancangan pertama sebagai kontrol adalah sampel air baku air minum yang langsung diambil dari sumur galian penduduk. Sedangkan rancangan kedua adalah sampel air baku air minum yang telah diberi perlakuan berupa penyaringan dengan menggunakan alat saringan yang memanfaatkan campuran arang aktif bamboo dan serbuk habbatussauda. Berdasarkan rancangan tersebut diharapkan alat saringan mampu menghasilkan air baku air minum yang memiliki nilai parameter kualitas air baku air minum yang lebih baik.

Karakteristik fisika, kimia, dan mikrobiologi sampel air baku air minum sebelum dan sesudah penyaringan disajikan dalam tabel 1 .

Tabel 1. Hasil Analisa Karakteristik Fisika, Kimia dan Mikrobiologi Air Baku

\begin{tabular}{|c|c|c|c|c|c|c|}
\hline \multirow{2}{*}{$\mathbf{N}$} & \multirow{2}{*}{ Karakteristik } & \multirow{2}{*}{ Satuan } & \multirow{2}{*}{ Syarat Mutu } & \multicolumn{2}{|c|}{ Hasil Uji } & \multirow{2}{*}{ Metoda uji } \\
\hline & & & & A & B & \\
\hline & FISIKA & 2 & & & 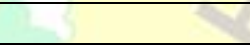 & 27 \\
\hline 1 & Suhu & ${ }^{\circ} \mathrm{C}$ & Suhu udara & 28 & 28 & SNI \\
\hline 2 & Warna & $\mathrm{mg} / \mathrm{l}$ & 100 & 16 & 20 & APHA AWWA \\
\hline 3 & $\mathrm{Bau}$ & - & $\begin{array}{l}\text { Tidak } \\
\text { berbau }\end{array}$ & $\begin{array}{l}\text { Berbau } \\
\text { Besi }\end{array}$ & $\begin{array}{l}\text { Bau Habba- } \\
\text { Tussauda }\end{array}$ & SNI \\
\hline 4 & Rasa & - & Tidak berasa & $\begin{array}{l}\text { Berasa } \\
\text { Sepat }\end{array}$ & $\begin{array}{l}\text { Berasa } \\
\text { Habatussauda }\end{array}$ & SNI \\
\hline \multirow[t]{3}{*}{5} & Kekeruhan & NTU & 5 & 2.5 & 2.5 & SNI \\
\hline & & & 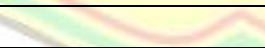 & 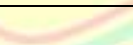 & $=$ & \\
\hline & KIMIA & & 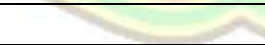 & 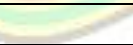 & & \\
\hline 1 & $\mathrm{pH}$ & & $6.5-8.5$ & 6.8 & 5.9 & pH meter \\
\hline 2 & Kesadahan & $\mathrm{mg} / \mathrm{L}$ & 500 & 140 & 66 & Titrimetri \\
\hline 3 & Kromium & $\mathrm{mg} / \mathrm{L}$ & 0.05 & $<0,196$ & $<0,196$ & AAS \\
\hline 4 & Sulfat & $\mathrm{mg} / \mathrm{L}$ & 250 & 3 & 3 & Spektrofotometri \\
\hline 5 & Flourida & $\mathrm{mg} / \mathrm{L}$ & 1,5 & 0,28 & 0,01 & Spektrofotometri \\
\hline 6 & Klorida & $\mathrm{mg} / \mathrm{L}$ & 250 & 9 & 9 & Titrimetri \\
\hline 7 & Nitrat & $\mathrm{mg} / \mathrm{L}$ & 50 & 0,8 & 0,6 & Spektrofotometri \\
\hline 8 & Nitrit & $\mathrm{mg} / \mathrm{L}$ & 3 & 0,016 & 0,002 & Spektrofotometri \\
\hline 9 & Mangan & $\mathrm{mg} / \mathrm{L}$ & 0,4 & 0,03 & 0,03 & AAS \\
\hline 10 & Besi & $\mathrm{mg} / \mathrm{L}$ & 0,3 & $<0,036$ & $<0,036$ & AAS \\
\hline & & & & & & \\
\hline
\end{tabular}




\begin{tabular}{|c|c|c|c|c|c|c|}
\hline \multirow{2}{*}{ No } & \multirow{2}{*}{ Karakteristik } & \multirow{2}{*}{ Satuan } & \multirow{2}{*}{ Syarat Mutu } & \multicolumn{2}{|c|}{ Hasil Uji } & \multirow{2}{*}{ Metoda uji } \\
\hline & & & & $\mathrm{A}$ & $\mathrm{B}$ & \\
\hline & $\begin{array}{l}\text { MIKRO } \\
\text { BIOLOGI }\end{array}$ & & & & & \\
\hline 1 & $\begin{array}{ll}\text { Angka lempeng } \\
\text { Total }\end{array}$ & Koloni/ml & - & $1,9 \times 10^{7}$ & $6 \times 10^{4}$ & APHA AWWA \\
\hline 2 & Total Coliform & $\begin{array}{l}\text { APM/ } \\
100 \mathrm{ml}\end{array}$ & 10.000 & $>1600$ & $>1600$ & APHA AWWA \\
\hline 3 & E.Coli & $\begin{array}{l}\text { APM/ } \\
100 \mathrm{ml}\end{array}$ & 2.000 & $<1,8$ & $<1,8$ & APHA AWWA \\
\hline 4 & Salmonela & $\begin{array}{l}\text { negatif/ } \\
100 \mathrm{ml}\end{array}$ & (-) negatif & $\begin{array}{l}(-) \\
\text { negatif }\end{array}$ & $\begin{array}{l}(-) \\
\text { Negatife }\end{array}$ & APHA AWWA \\
\hline
\end{tabular}

Keterangan:

Sampel A= Setelah Penyaringan dan B= Sampel Sebelum penyaringan

Syarat mutu berdasarakan Peraturan Pemerintah No 82 Tahun 2001 tentang pengelolaan kualitas air dan pengendalian pencemaran air, Permenkes RI Nomor 492/MENKES/PER/IV/2010 dan Kepmenkes No. 907/2002 tentang persyaratan kualitas air minum.

Resiko bahaya yang mungkin timbul dari air baku adalah adanya mikrobia pada air baku serta kandungan mineral yang tinggi. Hasil pengamatan terhadap kualitas air baku sebelum dan sesudah penyaringan menunjukkan bahwa air baku yang digunakan tidak memiliki resiko terhadap bahaya kimia, fisika dan mikrobiologi karena mengandung cemaran mikroba yang berada dibawah ambang batas dan $\mathrm{pH}$ rendah yaitu sebelum penyaringan berkisar 5.9 dan sesudah penyaringan 6.8 .

Dari tabel 1. terlihat bahwa kandungan $\mathrm{Fe}$ $(<0.036 \mathrm{mg} / \mathrm{l})$ dan $\mathrm{Mn}(0.03 \mathrm{mg} / \mathrm{l})$ pada sampel air baku sebelum dan sesudah proses penyaringan adalah sama tidak mengalami perubahan, Arang aktif bambu yang dimanfaatkan sebagai adsorben tidak akan meningkatkan kadar logam Fe dan Mn walaupun bambu secara alami mengandung senyawasenyawa $\mathrm{Fe}_{2} \mathrm{O}_{3}, \mathrm{~K}_{2} \mathrm{O}, \mathrm{SiO}_{2}, \mathrm{Mn}_{2} \mathrm{O}_{3}$ dan $\mathrm{S}$ yang sulit untuk dihilangkan dan tidak mengalami perubahan setalah dilakukan pembakaran dalam suasana vakum (inert) dalam furnace yang suhu dapat diatur dengan tepat pada suhu $400-800^{\circ}$ dan dianalisa dengan XRF ( $X$ ray fluorensesnce kualitatif) (Frillia, R.T.S., dkk, 2008). Begitu juga dengan kadar sulfat (3 ppm), klorida (9 ppm), fluorida $(0,01$ dan $0.28 \mathrm{mg} / \mathrm{l})$ dan kromium $(<0.196 \mathrm{mg} / \mathrm{l})$ pada data Tabel 1 . terlihat tidak mengalami perubahan sebelum dan sesudah penyaringan. Untuk kadar nitrit dan nitrat terlihat sedikit meningkat yaitu sebelum penyaringan nitrate $0.6 \mathrm{mg} / \mathrm{l}$ dan nitrit 0.002 $\mathrm{mg} / \mathrm{l}$ dan setelah perlakuan penyaringan nitrat
$0.8 \mathrm{mg} / \mathrm{l}$ dan nitrit $0.016 \mathrm{mg} / \mathrm{l}$, hal ini kemungkinan disebabkan kadar asam amino yang ada di dalam habbatussaudah. Berdasarkan daur nitrogen, asam amino akan terdekomposisi menjadi amoniak dan dengan adanya bakteri nitrifikasi maka amoniak akan dirubah menjadi anion nitrat dan nitrit. Komposisi nutrisi habbatussaudah adalah protein $21 \%$, karbohidrat $35 \%$, lemak $38 \%$ dan sisanya alfatokoferol, pitosterol, nigellone,thyomoquinone, kaempferol dan quercetine (Salma, 2012). Hasil penelitian kesadahan memperlihatkan peningkatan kadar sebelum penyaringan $66 \mathrm{mg} / \mathrm{l}$ dan seseudah penyaringan $140 \mathrm{mg} / \mathrm{l}$. Kesadahaan (hardness) adalah gambaran kation divalen (valensi dua) yaitu nilai $\mathrm{Ca}, \mathrm{Mg}, \mathrm{Mn}, \mathrm{Fe}$ dan $\mathrm{Si}$. Kalsium dan magnesium berikatan dengan anion penyusun alkalinitas yaitu bikarbonat dan karbonat. Keberadaan kation lain misalnya besi valensi dua dan tiga, stronsium, mangan, alumunium sebenarnya juga memberikan kontribusi terhadap nilai kesadahan tota (Effendi, H. 2003). Kemungkinan peningkatan nilai kesadahan disebabkan oleh kandungan kation-kation $\mathrm{Si}$, $\mathrm{Mn}$ dan $\mathrm{Fe}, \mathrm{K}, \mathrm{Sr}$ dan $\mathrm{Al}$ pada arang bambu, dimana $1 / 3$ komposisi arang bambu adala $\mathrm{SiO}_{2}$. Selain itu, dapat juga berasal dari pasir dan batu kerikil pada alat saringan. Nilai yang diperlihatkan oleh parameter kimia pada penelitian ini menunjukkan nilai yang masih dibawah ambang batas baku mutu air baku untuk air minum PP No. 82 Tahun 2001 dan masih layak digunakan sebagai sumber air baku untuk air minum. 
Parameter analisis mikrobiologi yang dilakukan adalah penetapan angka lempeng total bakteri, total coliform, E. Coli, dan Salmonella. Hasil pengujian penetapan angka lempeng total bakteri pada air baku yang diberi perlakuan penyaringan dengan campuran arang bamboo dan habbatussauda memberikan hasil sebesar 5.7 x $10^{7}$ sedangkan air baku tanpa diberi perlakuan

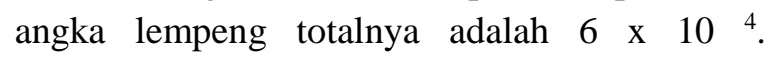
berdasarkan PP 82 tahun 2001 dan Permenkes 492/Menkes/Per/IV/2010, tidak menetapkan batas maksimum angka lempeng total pada air baku baik untuk cemaran bakteri maupun jamur karena menurut permenkes sumber air baku untuk olahan sebelum siap digunakan sebagai air minum. Terdapatnya selisih angka lempeng total dari dua perlakuan ini kemungkinan disebabkan pada tahap analisa mikrobiologi terdapat perbedaan waktu pengiriman sampel dan suhu penyimpan sampel. Angka lempeng total sampel tanpa perlakuan lebih rendah dibandingkan angka lempeng total sampel yang diberikan perlakuan campuran habbatausaudah. Hal ini kemungkinana sampel tanpa perlakuan adalah sampel segar dan langsung dianalisa. Sedangkan sampel yang diberikan perlakuan penyaringan dengan habatausaudah disimpan di suhu $4^{\circ} \mathrm{C}$ selama 3 hari untuk kemudian dianalisa.

Hasil pengujian total coliform, E coli dan Salmonela menunjukkan bahwa tidak terdapat perubahan nilai baik sampel yang diberikan perlakuan penyaringan dengan campuran habbataussaudah maupun sampel tanpa perlakuan. Nilai parameter mikrobiologi yang diperlihatkan pada penelitian ini masih dibawah ambang batas baku mutu air baku untuk air minum atau air kelas I pada PP no 82 Th 2001.

\section{KESIMPULAN}

1. Pembuatan karbon aktif dari arang bambu yang memiliki rendemen yang lebihbesar (50\%) yaitu dengan metode tungku sederhana.

2. Campuran karbon aktif dari arang bambu dan serbuk habatussasuda memiliki kemampuan sebagai adsorben pada penyaring air baku untuk air minum berdasarkan nilai parameter fisika, kimia dan mikrobiologi.
3. Alat saringan air yang dihasilkan mudah, murah, akan tetapi belum efektif berdasarkan nilai parameter fisika, kimia dan mikrobiologi, walaupun nilai tersebut masih dibawah ambang batas baku mutu air baku air miunum yang ditetapkan pada Peraturan Pemerintah No 82 Tahun 2001 tentang pengelolaan kualitas air dan pengendalian pencemaran air, Peraturan Menteri Kesehatan RI tentang Persyaratan Kualitas Air Minum (Permenkes RI Nomor492/MENKES/PER/IV/2010 dan Kepmenkes No. 907/2002).

\section{DAFTAR PUSTAKA}

Achanta, G., Modzelewska, A., Feng, L., Khan, S.R., Huang, P., 2006, "A Boronicchalcone Derivative Exhibits Potent Anticancer Activity through Inhibition of the Proteasome", Molecular Pharmacology, 70(1), 426-433.

Abdulelah, H.A.A and Abidin, Z.B.A.H. 2007. In Vivo Anti- malarial Test of Nigella sativa (Black Seed) Different Extracts. American journal of Pharmacology and Toxicology 2(2):46-50

Effendi, H., 2003. Telaah Kualitas Air Bagi Pengelolaan Sumberdaya danLingkungan. Cetakan 1. Kanisius. Yogyakarta

Frillia, R.T.S., Handoko, E., Soegijono, B., dan Agustriany, R. 2008, Pengaruh Temperatur terhadap Pembentukan Pori pada Arang Bambu, Prosiding Seminar Nasional Sain dan Teknologi-II Univ. Lampung. (ISBN:978-979-1165-74-7

Kannan, N., And Veemaraj, 2009, Removal of lead (II) by Adsorption onto Bamboo Dust and Commercial Activated Carbons-A Comaprative Study. E-Journal of Chemistry. 6(2), 247-256 (ISSN: 09734945)

Salma, 2012. Khasiat Habbatussauda. Majalah Kesehatan. http//www. majalah kesehatan.com 